\title{
Statistical Investigation of Correlation between Cardiovascular Event ad Hypertension
}

\author{
Linfei Dai ${ }^{1, a, a^{*}, \dagger}$, Mingyang Song ${ }^{2, b, *, \dagger}$ and Danni Zhang ${ }^{3, c, *, \dagger,}$ \\ ${ }^{1}$ School of China Medical University, Shenyang, Province Liaoning (110122), China; \\ ${ }^{2}$ University of British Columbia, British Columbia, Vancouver (V6T 1Z4), Canada; \\ ${ }^{3}$ School of Nanjing Medical University, Nanjing, Province Jiangsu (210000), China; \\ †These authors contributed equally.
}

\begin{abstract}
Cardiovascular disease is one of the most severe health killers in modern life. In this study, the association among the risk of cardiovascular diseases, patients' blood pressure and treatment was analyzed. This study makes a secondary analysis on the data from the Evidence for Cardiovascular Prevention from Observational Cohorts in Japan (EPOCH-JAPAN) database. Participants have recruited 39705 representative participants with diverse blood pressure. The results show that the treated participants have a higher proportion of diabetes mellitus, dyslipidemia, and history of cardiovascular diseases $(\mathrm{P}<0.0001)$, compared with untreated participants. During the 10-year follow-up period, there were 2032 cardiovascular deaths distributed among coronary heart disease(CHD), heart failure, and stroke. The treated participants showed an significantly risk for cardiovascular mortality (Hazard ratios (HR):1.5; 95\% confidence intervals (CI):1.36-1.66), CHD (HR:1.53, 95\%CI: 1.23-1.9), heart failure (HR:1.39; 95\%CI: 1.09-1.76) and stroke (HR:1.48; 95\%CI: 1.28-1.72). Especially for the participants under antihypertensive medication, their risk of cardiovascular mortality was 1.5 times higher than that of the untreated participants .
\end{abstract}

\section{Introduction}

Cardiovascular disease, like coronary heart disease, heart failure, disease stroke, has become a significant disease endangering human health, bringing heavy economic and spiritual burden to individuals, families, and society. The risk factors of cardiovascular disease are common in the population, such as hypertension, hyperlipidemia, hyperglycemia, obesity and smoking cardiovascular disease (CVD) is the leading cause of death in Japan (28\% of death) and is a multi-factor disease that seriously affects national health. Although the mortality from CHD and stroke has declined since 1960, this may be due to changes in people's lifestyles, such as lower sodium intake, which has reduced the risk of CVD from hypertension. However, hypertension remains a significant risk and prognostic factor for CVD [2].

Therefore, CVD has become a significant public health problem affecting national health, and it is urgent to strengthen the prevention and treatment of CVD.

Hypertension is a major risk factor for CVD, accounting for approximately $54 \%$ of stroke incidence worldwide [3]. Reducing blood pressure in patients with hypertension can reduce the incidence of CVD. The morbidity, mortality, and disease burden of CVD caused by hypertension in recent ten years are worrying. Disease risk factors are on the incidence of complex diseases $[4,5]$. However, targeting different populations and whether or not they have been treated for hypertension has other implications for CVD research.

Previous studies showed that there is a strong positive correlation between blood pressure level and CVD risks. For participants who have been treated for hypertension, few studies continue to follow up on the effect of later hypertension on the risk of CVD [6].

This study is aimed to correlate the risk of different types of CVD based on the participants' BP levels and the current status of treatment of hypertension.

\section{Methods}

\subsection{Study Population}

The present study aimed to examine sex, age-group risk ratios, and the impact on overall mortality and blood pressure to estimate the contribution of hypertensive allcause mortality by performing a meta-analysis of data from 13 population-based cohort studies in Japan.

The epoch-making Japan study is a pooled analysis of 13 cohort studies that examined the relationship between health indicators (laboratory indicators, lifestyle, and behavioral factors) and disease (mortality and morbidity) of the Japanese population. The criteria for inclusion in this Meta-analysis include: health examination measures were collected, followed up for

\footnotetext{
Corresponding author: a Idai02@qub.ac.uk, ${ }^{b} S C h r i s t i n a 0214 @ g m a i l . c o m{ }^{c} z d n 011027 @ 163 . c o m$
} 
about ten years, and $>1000$ participants were included. Both national and single-point cohort studies are included. The names of the cohort studies are shown in Table 1. Participants were age at entry (40-90 years) and the availability of information such as gender, age at entry, and systolic and diastolic blood pressure. Since the end time of follow-up was different in each cohort, the follow-up age range was limited to 40-90 years old and the end time of observation was set at 90 years old.

Table 1. Baseline Characteristics for male participants

\begin{tabular}{|c|c|c|c|c|c|c|c|}
\hline \multirow{2}{*}{$\begin{array}{l}\text { Cohort } \\
\text { Name }\end{array}$} & \multirow{2}{*}{$\begin{array}{l}\text { Geogra } \\
\text { phic } \\
\text { Locatio } \\
n\end{array}$} & \multirow{2}{*}{$\begin{array}{l}\text { Number } \\
\text { of } \\
\text { Particip } \\
\text { ants }\end{array}$} & \multirow{2}{*}{$\begin{array}{l}\text { Age } \\
\text { (Mean/Sta } \\
\text { ndard } \\
\text { Deviation } \\
\text { ) }\end{array}$} & \multicolumn{4}{|c|}{ Blood pressure } \\
\hline & & & & $\begin{array}{r}\text { Systc } \\
(\mathrm{M} \\
\text { Stan } \\
\text { Devi } \\
\mathrm{n}\end{array}$ & $\begin{array}{l}\text { lic } \\
\text { an } \\
\text { lard } \\
\text { atio }\end{array}$ & $\begin{array}{l}\mathrm{Di} \\
(\mathrm{M} \\
\mathrm{Sta} \\
\mathrm{De}\end{array}$ & \\
\hline $\begin{array}{l}\text { Tanno } \\
\text { Sobetsu }\end{array}$ & $\begin{array}{l}\text { Hokkai } \\
\text { do }\end{array}$ & 840 & $51 / 7$ & 132 & 20 & 82 & 10 \\
\hline Osaki & Miyagi & 6918 & $63 / 10$ & 133 & 17 & 80 & 11 \\
\hline Ohasama & Iwate & 1122 & $61 / 11$ & 135 & 17 & 76 & 11 \\
\hline Oyabe & $\begin{array}{l}\text { Ishika } \\
\text { wa }\end{array}$ & 1509 & $61 / 10$ & 131 & 20 & 79 & 11 \\
\hline $\begin{array}{l}\text { Ykk } \\
\text { workers }\end{array}$ & $\begin{array}{l}\text { Toyam } \\
\text { a }\end{array}$ & 3177 & $51 / 6$ & 121 & 15 & 74 & 12 \\
\hline $\begin{array}{l}\text { SPMI } \\
\text { cohort }\end{array}$ & Shiga & 1939 & $54 / 8$ & 133 & 18 & 81 & 11 \\
\hline Suita & Osaka & 2339 & $60 / 11$ & 131 & 21 & 80 & 12 \\
\hline $\begin{array}{l}\text { RERF } \\
\text { cohort }\end{array}$ & $\begin{array}{l}\text { Hiroshi } \\
\text { ma }\end{array}$ & 1506 & $60 / 13$ & 135 & 22 & 85 & 12 \\
\hline $\begin{array}{l}\text { Hisayam } \\
\mathrm{a}\end{array}$ & $\begin{array}{l}\text { Fukuok } \\
\text { a }\end{array}$ & 1113 & $58 / 12$ & 135 & 20 & 81 & 11 \\
\hline $\begin{array}{l}\text { JACC } \\
\text { study }\end{array}$ & $\begin{array}{l}\text { Nation } \\
\text { wide }\end{array}$ & 11041 & $58 / 10$ & 135 & 19 & 81 & 11 \\
\hline $\begin{array}{l}\text { NIPPON } \\
\text { DATA80 }\end{array}$ & $\begin{array}{l}\text { Nation } \\
\text { wide }\end{array}$ & 3161 & $56 / 11$ & 142 & 22 & 85 & 12 \\
\hline $\begin{array}{l}\text { NIPPON } \\
\text { DATA90 }\end{array}$ & $\begin{array}{l}\text { Nation } \\
\text { wide }\end{array}$ & 2759 & $57 / 11$ & 140 & 20 & 85 & 12 \\
\hline Ibaraki & Ibaraki & 33134 & $61 / 10$ & 137 & 17 & 81 & 11 \\
\hline
\end{tabular}

Table 2. Baseline Characteristics for women participants.

\begin{tabular}{|c|c|c|c|c|c|c|c|}
\hline \multirow{2}{*}{$\begin{array}{l}\text { Cohort } \\
\text { Name }\end{array}$} & \multirow{2}{*}{$\begin{array}{l}\text { Geographi } \\
\text { c } \\
\text { Location }\end{array}$} & \multirow{2}{*}{$\begin{array}{l}\text { Number } \\
\text { of } \\
\text { Participa } \\
\text { nts }\end{array}$} & \multirow{2}{*}{$\begin{array}{l}\text { Age } \\
\text { ( } \\
\text { Mean/ } \\
\text { Standard } \\
\text { Deviatio } \\
\text { n) }\end{array}$} & \multicolumn{4}{|c|}{ Blood pressure } \\
\hline & & & & \multicolumn{2}{|c|}{$\begin{array}{l}\text { Systolic } \\
\text { (Mean } \\
\text { Standard } \\
\text { Deviation) }\end{array}$} & \multicolumn{2}{|c|}{$\begin{array}{l}\text { Diastolic } \\
\text { (Mean } \\
\text { Standard } \\
\text { Deviation) }\end{array}$} \\
\hline $\begin{array}{l}\text { Tanno } \\
\text { Sobetsu }\end{array}$ & Hokkaido & 971 & $51 / 7$ & 134 & 20 & 82 & 10 \\
\hline Osaki & Miyagi & 9312 & $62 / 9$ & 130 & 18 & 78 & 11 \\
\hline Ohasama & Iwate & 1678 & $60 / 10$ & 130 & 17 & 73 & 11 \\
\hline Oyabe & Ishikawa & 3208 & $58 / 10$ & 126 & 20 & 75 & 11 \\
\hline $\begin{array}{l}\text { Ykk } \\
\text { workers }\end{array}$ & Toyama & 1724 & $50 / 6$ & 115 & 15 & 70 & 11 \\
\hline $\begin{array}{l}\text { SPMI } \\
\text { cohort }\end{array}$ & Shiga & 2596 & $55 / 8$ & 132 & 17 & 79 & 10 \\
\hline Suita & Osaka & 2619 & $58 / 11$ & 129 & 22 & 77 & 12 \\
\hline $\begin{array}{l}\text { RERF } \\
\text { cohort }\end{array}$ & Hiroshima & 3121 & $63 / 12$ & 135 & 23 & 81 & 12 \\
\hline Hisayama & Fukuoka & 1518 & $59 / 12$ & 133 & 22 & 76 & 11 \\
\hline $\begin{array}{l}\text { JACC } \\
\text { study }\end{array}$ & $\begin{array}{l}\text { Nationwid } \\
\mathrm{e}\end{array}$ & 19210 & $57 / 9$ & 132 & 19 & 78 & 11 \\
\hline $\begin{array}{l}\text { NIPPON } \\
\text { DATA80 }\end{array}$ & $\begin{array}{l}\text { Nationwid } \\
\text { e }\end{array}$ & 4020 & $58 / 11$ & 139 & 22 & 81 & 12 \\
\hline
\end{tabular}

\begin{tabular}{|l|l|l|l|l|l|l|l|}
\hline $\begin{array}{l}\text { NIPPON } \\
\text { DATA90 }\end{array}$ & $\begin{array}{l}\text { Nationwid } \\
\mathrm{e}\end{array}$ & 3697 & $58 / 12$ & 138 & 20 & 81 & 12 \\
\hline Ibaraki & Ibaraki & 63909 & $59 / 10$ & 132 & 18 & 78 & 11 \\
\hline
\end{tabular}

Table 3. Baseline Characteristics of EPOCH-JAPAN distinguished by Japan Atherosclerosis Society(JAS) classification

\begin{tabular}{|l|c|c|c|c|c|c|}
\hline & \multicolumn{6}{|c|}{$\begin{array}{l}\text { Category for LDL-c management proposed by JAS } \\
\text { Guidelines 2012 }\end{array}$} \\
\hline & \multicolumn{3}{|c|}{ Men } & \multicolumn{3}{c|}{ Women } \\
\hline & I & II & III & I & II & III \\
\hline Age,years(SD) & $\begin{array}{c}46( \\
5)\end{array}$ & $58(6)$ & $57(10$ & $51(7)$ & $67(3)$ & $58(1$ \\
& 9.8( & $9.5(1$ & $9.3(2$. & $9.8(0$. & $9.6(1$. & $9.4(2$ \\
& $0.9)$ & $.5)$ & $0)$ & $9)$ & $5)$ & $0)$ \\
\hline Person year(SD) & 121 & 131( & $133(1$ & $126(1$ & $137(2$ & 131( \\
& $(15)$ & $18)$ & $9)$ & $9)$ & $0)$ & $20)$ \\
\hline $\begin{array}{l}\text { Systolic blood } \\
\text { pressure,mmHg(SD) }\end{array}$ & $\begin{array}{c}186 \\
(30)\end{array}$ & $\begin{array}{c}200( \\
34)\end{array}$ & $\begin{array}{c}199(3 \\
6)\end{array}$ & $\begin{array}{c}210(3 \\
7)\end{array}$ & $\begin{array}{c}227(3 \\
8)\end{array}$ & $\begin{array}{c}213( \\
37)\end{array}$ \\
\hline $\begin{array}{l}\text { Total } \\
\text { glucose,mg/dL(SD) }\end{array}$ & 96( & 101( & $106(3$ & $95(13$ & $102(1$ & 103( \\
\hline $\begin{array}{l}\text { Blood glucose,mg/dL( } \\
\text { SD) }\end{array}$ & $13)$ & $19)$ & $2)$ & ) & $9)$ & $28)$ \\
\hline $\begin{array}{l}\% \text { of those having } \\
\text { glucose } \geq 200 \mathrm{mg} / \mathrm{dL}\end{array}$ & 0 & 0 & 2.2 & 0 & 0 & 1.7 \\
\hline Current Smoker(\%) & 56.6 & 55.4 & 53.0 & 8.3 & 11.5 & 6.7 \\
\hline Number of Stroke & 0 & 8 & 81 & 4 & 8 & 85 \\
\hline $\begin{array}{l}\text { Number of Ischemic } \\
\text { Stroke }\end{array}$ & 0 & 2 & 33 & 1 & 4 & 25 \\
\hline $\begin{array}{l}\text { Number of } \\
\text { Hemorrhagic Strokes }\end{array}$ & 0 & 2 & 24 & 1 & 3 & 12 \\
\hline $\begin{array}{l}\text { Number of } \\
\text { Subarachnoid } \\
\text { hemorrhage }\end{array}$ & 0 & 2 & 13 & 0 & 1 & 22 \\
\hline $\begin{array}{l}\text { Number of Coronary } \\
\text { Artery Disease }\end{array}$ & 1 & 10 & 69 & 1 & 8 & 31 \\
\hline & & & & & & \\
\hline
\end{tabular}

\subsection{Research Variable}

Blood Pressure Measurement

A mercury sphygmomanometer or a certified computerized monitor was used to measure Blood pressure Wen participants in the seated position. The Participants were requested to rest before measurement without Ohsaki.22.The participants were classified into six categories according to their blood pressure levels optimal (12080 mmHg); normal (120-12980-84 mmHg); high average (130-13985-89 $\mathrm{mmHg})$; grade 1 hypertension (140-15990-99 $\mathrm{mmHg}) ;$ grade 2 hypertension (160-179100-109 $\mathrm{mmHg})$; and grade 3 hypertension $(\geqslant 180 \geqslant 110 \mathrm{mmHg}$ ). The subject was distributed to the higher level if a systolic or diastolic blood pressure was at a different level. Depending on whether the participants received antihypertensive medications or not, they were further divided. The outcome was that all participants were assigned to 1 of 12 blood pressure--based and treatment-based categories.

\subsection{Statical Analysis}

The JASP software (version 0.14.1) was utilized in this study. This study employs t-test, analysis of variance, test as statistical measures to exhibit and interpret results. The most commonly used method of health risk assessment is a multi-factor model method, which is based on multi-factor mathematical analysis; that is, the 
relationship model between disease risk and risk factors is obtained by using the method of statistical probability theory. It can include a variety of risk factors at the same time.

The model adopted to examine the correlation between blood pressure level and cardiovascular disease mortality is the Cox regression model. The Cox models reflect the comprehensive risk of morbidity or mortality of the main risk factors of an individual; it is also called the comprehensive risk of cardiovascular disease (total risk). The average risk factor adjusts the absolute risk and the average incidence rate of the population to the Cox survival function; for example, the ten-year risk probability $(\mathrm{P})$ formula is:

$$
P=1-S_{o}(t)^{\exp (f(x, M))}
$$

where

$$
f(x, M)=\beta_{1}\left(x_{1}-M_{1}+\cdots+\beta_{p}\left(x_{p}-M_{p}\right) \cdot \beta_{1}, \ldots, \beta_{p}\right.
$$

are partial regression coefficients of different risk factors; represent the level of each risk factor, stand for the average levels of risk factors in the studied group. S0 (T) is the average survival function at the time of $\mathrm{T}$, that is, the survival function at the average level of risk factors.

Risk factors including age, sex, body mass index, records of cardiovascular disease, smoking (current, past, never), and habitual drinking (current, past, never). For participants who have unknown cardiovascular disease history, smoking habit, and drinking habit, it can adjust confounding by calculating the p-value. Statistical significance of $p$-value was an $\alpha$-level of $<0.05$ on 2 sided tests.

\section{Results}

Table 2 presents the baseline characteristics of the 39,705 participants according to blood pressure category and treatment status. Among all participants, 23176 (58.4\%) were female, 21099 (53.1\%)were $\geq 60$ years of age, $3966(10.1 \%)$ had previous experience of cardiovascular disease, 14374 (38.8\%) were current, or non-smokers, $16573(44.7 \%)$ were current or nondrinkers, $2982(7.9 \%)$ had diabetes, and $6628(17.2 \%)$ of participants had dyslipidemia. Characteristics of participants treated with antihypertensive medications are summarized in Table 1. Compared with untreated participants, treated participants had a significantly higher prevalence of diabetes mellitus, dyslipidemia, and history of cardiovascular disease $(\mathrm{P}<0.0001)$ but significantly lower rates of current or quit smoking $(\mathrm{P}=0.0003)$. Systolic and diastolic blood pressure levels in treated participants were 146.0 and $84.3 \mathrm{mmHg}$, which were $14.1 \mathrm{mmHg}$ (95\% confidence interval [CI], 13.6-14.6; $\mathrm{P}<0.0001)$ and $5.3 \mathrm{mmHg}(95 \% \mathrm{CI}, 5.0-5.6$; $\mathrm{P}<0.0001$ ), higher than those of untreated participants. The median follow-up time for the overall study population was 10.0 years (5th- 95 th percentile interval, 3.2-19.0 years), ranging from 6.5 years in Osaki to 19.0 years in NIPPON DATA 80 (Table 1). The risk of cardiovascular death in the untreated population was increasing in the treated population ( $\mathrm{P} \leq 0.0072$ ), from $39 \%$ ( $95 \% \mathrm{CI}, 9 \%-76 \%$ ) for heart failure to $53 \%$ ( $95 \%$
CI, $23 \%-90 \%$ ) for that for coronary artery disease (Table 3 ). The results were grouped by sex (male to female ratio), age ( $<60$ years vs $\geq 60$ years), and overweight (body mass index $<25 \mathrm{vs} \geq 25 \mathrm{~kg} / \mathrm{m} 2$ ) as shown in Table 3. Except for the age factor, there was no significant interaction between antihypertensive drugs and mortality subgroups ( $\mathrm{P} \geq 0.30$ ). Similar results were observed when systolic blood pressure levels were excluded from the adjustment factors of the model. Adjustment factors for the model (Table S2). the assumption of heterogeneity was rejected for the six cohorts. The heterogeneity hypothesis was rejected for the six cohorts with respect to cardiovascular death $(\mathrm{P}=0.45$ for heterogeneity) as well as sub-types of cardiovascular death. Figure 2 shows the risk for each of the 12 groups according to 6 combinations of blood pressure level and treatment status. In untreated participants, the risk increased linearly with increasing blood pressure.

Risk increased linearly with increasing blood pressure category, independent of the cause of death $(\mathrm{P} \leq 0.011)$. There was a significant linear relationship between total cardiovascular mortality and blood pressure levels. A significant linear relationship was observed for blood pressure levels in treated participants $(\mathrm{P}=0.0003)$. And no stepwise increase in stroke risk was observed in treated participants, and no stepwise increase in stroke risk was observed in treated participants $(\mathrm{P}=0.19)$. In this 8098 treated population, the relationship between blood pressure levels and the risk of stroke death can be measured by quadratic term for blood pressure $(\mathrm{P}=0.024)$. However, the log likelihood test showed that the Cox model, including the quadratic term, did not significantly improve stroke mortality.

The improvement in stroke mortality in the Cox model, including the quadratic term, was not significant compared with the model with the quadratic term $(p=0.13)$. When excluding 3966 participants with a history of cardiovascular disease (Figure S1). Risk increased linearly with increasing blood pressure category. Among the 29191 untreated participants, the risk increased linearly with increasing blood pressure category regardless of mortality sub-type. Mortality subtype $(\mathrm{P} \leq 0.0039)$, although the increased risk was not significant in the 6548 treated participants $(\mathrm{P} \geq 0.10)$. Similar to the main analysis, blood pressure of treated.Similar to the main analysis, blood pressure levels in treated patients were also curvilinearly associated with stroke mortality was curvilinearly related to stroke mortality $(\mathrm{P}=0.0076)$, whereas the improvement of the model was not significant $(\mathrm{P}=0.094)$. Participants were stratified by sex, age $(<60$ versus $\geq 60$ years), and body mass index ( $<25$ versus $\geq 25 \mathrm{~kg} / \mathrm{m} 2$ ) confirmed the main analysis results as described in Tables S3 through S8. Risk trends for each subgroup are shown in Table 4.

The incremental risk for the blood pressure category was higher in younger participants $(<60$ years; $22 \%$ to $79 \%$ ) than in older adults (60 years $7 \%$ to $15 \%$ ), and significant interactions were observed. Significant interactions were observed for total cardiovascular, heart failure, and stroke mortality.(Table $4 ; \mathrm{P} \leq 0.026$ ). 
The interaction with blood pressure was also significant in patients treated for coronary heart disease death at age. The interaction with blood pressure was also significant in patients not receiving treatment, including the effect of age on death from coronary heart disease $(\mathrm{P}=0.011)$, body mass index on cardiovascular disease $(\mathrm{P}=0.034)$, and stroke $(\mathrm{P}=0.016)$.

\section{Discussion}

In EPOCH-Japan, most of the cohort study participants were community residents or workers who participated in annual physical examinations under the Health Services Act [7]. Thus, participants in EPOCH-Japan can be considered highly motivated to stay healthy. In addition, participants in the annual physical examination can usually continue to receive health education or counseling at the time of the physical examination after completion of the baseline survey. In addition, workers must undergo an annual physical examination in accordance with the law, and their health conditions shall be strictly controlled after each physical examination. As a result, the participants in EPOCHJapan may be healthier than the average Japanese. A previous study reported that participants who had annual checkups had significantly lower rates of cardiovascular disease and mortality than non-participants [8].

For CHD, the absolute difference between mean estimated and actual mortality was relatively small in the low mortality group. However, in the group with higher mortality from CHD, the average estimated mortality was much higher than the actual mortality. For stroke,

the average estimated mortality rate for both men and women was almost in line with the actual mortality rate in the low/moderate mortality group, and the average estimated mortality rate was higher than the actual mortality rate in the high estimated mortality group. In all three categories of the 2012 JAS guidelines, the

average estimated mortality rate from coronary heart disease was higher than the actual mortality rate. However, there was no significant increase in the actual mortality of men in Category 3 compared with Category 2 , while the actual mortality of women in Category 3 was lower than in Category 2. (Table 3). When this study did not take diabetes into account in the risk classification, the actual mortality rates for both men and women increased in increasing order by category.

Previous studies have clearly shown that negative psychological factors, individual characteristics, and mental health disorders all affect patients' cardiovascular health. While many studies have linked cardiovascular disease risk to specific negative emotions, many researchers say there is an overlap. Specific emotions have distinct neurobiological and behavioral characteristics that contribute specifically to cardiovascular disease health risk.

Depression, chronic stress, anxiety, anger, pessimism, and unhealthy living are associated with potentially harmful biological reactions, including heart rate/arrhythmia, digestive discomfort, increased blood pressure and inflammation, and decreased blood flow to the heart.

The cumulative effect of daily stress and traumatic events also increases the risk of cardiovascular disease. Studies have shown that general anxiety and workrelated stress (self-reported by patients) are associated with a 40 percent increased risk of cardiovascular disease and death [9].

Besides, negative psychology is associated with an increase in behaviors that increase the risk of cardiovascular disease, including smoking, low physical activity, unhealthy diet, being overweight, and poor medication adherence.

The guidelines recommend regular mental health check-ups for people with and suspected cardiovascular disease, noting that psychotherapy and psychosomatic programs benefit cardiovascular health. The relative risk (RR) of negative psychological factors associated with cardiovascular risk is shown in Table 4.

At present, there is no single universal definition of positive psychological factors. In the statement, positive mental health factors include positive psychology, such as happiness, optimism, gratitude, a sense of purpose, life satisfaction, etc. Previous research has noted that conceptually all aspects of positive psychology are similar. Still, a large body of research suggests that each mental health factor is different in importance and may have other effects on health-related outcomes.In addition, positive mental health means more than the absence of negative psychological factors such as depression, anxiety, and pessimism. The lack of mental distress does not mean that you are experiencing positive mental health. So far, the findings suggest that positive psychological factors are independently associated with the occurrence of cardiovascular disease, not just the absence of a negative state. Studies have also shown that positive mental health factors (including happiness, gratitude, a sense of purpose, life satisfaction, and mindfulness) are associated with reduced risk of cardiovascular disease and increased health-promoting behaviors (including smoking cessation, increased physical activity, wellness factors, increased adherence to medications, regular checkups, and health screenings) [10]. People with better mental health also tend to have more positive social relationships and connections, contributing to a healthier adaptation to life's challenges. The RR risk and prevalence associated with positive psychological factors for cardiovascular health and prognosis are shown in Table 5. Overall, most studies have found that several positive psychological factors are associated with reduced cardiovascular disease and mortality, as well as behavioral and biological factors, which may be intermediate factors with significant associations.

\section{Conclusion}

This study evaluates the correlation between the risk of different types of CVD based on the participants' BP levels and the current status of treatment of hypertension via a secondary statistical analysis on the Evidence for 
Cardiovascular Prevention from Observational Cohorts in Japan (EPOCH-JAPAN) database. This paper also considers negative psychology as a factor that could increase the risk of cardiovascular disease and take it into a discussion.

Table 4 Baseline Characteristics and Blood Pressure Definitions of Participants by Antihypertensive Medication .

\begin{tabular}{|c|c|c|c|c|c|c|}
\hline $\begin{array}{l}\text { Characteristi } \\
\text { cs }\end{array}$ & Optima & $\begin{array}{l}\text { Norm } \\
\text { al }\end{array}$ & $\begin{array}{l}\text { High } \\
\text { Normal }\end{array}$ & $\begin{array}{l}\text { Grade } 1 \\
\text { Hypertensi } \\
\text { on }\end{array}$ & $\begin{array}{l}\text { Grade } \\
2 \\
\text { Hyper } \\
\text { tensio } \\
\mathrm{n}\end{array}$ & $\begin{array}{l}\mathrm{P} \\
\text { valu } \\
\mathrm{e}\end{array}$ \\
\hline \multicolumn{7}{|l|}{$\begin{array}{l}\text { Untreated } \\
\text { participants } \\
(\mathrm{n}=31607)\end{array}$} \\
\hline Number & 6714 & 6588 & 7446 & 7606 & 2477 & \\
\hline Women, \% & $\begin{array}{l}4521 \\
(67.3)\end{array}$ & $\begin{array}{l}3897 \\
(59.2)\end{array}$ & $\begin{array}{l}4162 \\
(55.9)\end{array}$ & $\begin{array}{l}4017 \\
(52.8)\end{array}$ & $\begin{array}{l}1291 \\
(52.1)\end{array}$ & $\begin{array}{l}<0.0 \\
001\end{array}$ \\
\hline $\begin{array}{l}\text { History of } \\
\text { cardiovascul } \\
\text { ar } \\
\text { disease, \% }\end{array}$ & $\begin{array}{l}256 \\
(3.8)\end{array}$ & $\begin{array}{l}278 \\
(4.3)\end{array}$ & $\begin{array}{l}335 \\
(4.5)\end{array}$ & $896(11.9)$ & $\begin{array}{l}461 \\
(19.0)\end{array}$ & $\begin{array}{l}<0.0 \\
001\end{array}$ \\
\hline $\begin{array}{l}\text { Diabetes } \\
\text { mellitus, \% }\end{array}$ & $\begin{array}{l}220 \\
(3.5)\end{array}$ & $\begin{array}{l}270 \\
(4.3)\end{array}$ & $\begin{array}{l}401 \\
(5.7)\end{array}$ & $559(7.6)$ & $\begin{array}{l}267 \\
(11.1)\end{array}$ & $\begin{array}{l}<0.0 \\
001\end{array}$ \\
\hline $\begin{array}{l}\text { Dyslipidemi } \\
\text { a, \% }\end{array}$ & $\begin{array}{l}864 \\
(13.1)\end{array}$ & $\begin{array}{l}901 \\
(14.0)\end{array}$ & $\begin{array}{l}1167 \\
(16.0)\end{array}$ & $\begin{array}{l}1288 \\
(17.4)\end{array}$ & $\begin{array}{l}446 \\
(18.4)\end{array}$ & $\begin{array}{l}<0.0 \\
001\end{array}$ \\
\hline $\begin{array}{l}\text { Current or } \\
\text { ex- } \\
\text { smoker, \% }\end{array}$ & $\begin{array}{l}2126 \\
(34.0)\end{array}$ & $\begin{array}{l}2344 \\
(37.8)\end{array}$ & $\begin{array}{l}2724 \\
(39.7)\end{array}$ & $\begin{array}{l}3034 \\
(42.4)\end{array}$ & $\begin{array}{l}1038 \\
(43.9)\end{array}$ & $\begin{array}{l}<0.0 \\
001\end{array}$ \\
\hline $\begin{array}{l}\text { Current or } \\
\text { ex-drinking } \\
\text { habits, } \%\end{array}$ & $\begin{array}{l}2418 \\
(38.6)\end{array}$ & $\begin{array}{l}2640 \\
(42.5)\end{array}$ & $\begin{array}{l}3228 \\
(46.6)\end{array}$ & $\begin{array}{l}3424 \\
(47.6)\end{array}$ & $\begin{array}{l}1152 \\
(49.5)\end{array}$ & $\begin{array}{l}<0.0 \\
001\end{array}$ \\
\hline Age, y(SD) & $\begin{array}{l}56.2 \\
(10.5)\end{array}$ & $\begin{array}{l}56.8 \\
(10.5)\end{array}$ & $\begin{array}{l}59.1 \\
(10.5)\end{array}$ & $60.5(10.8)$ & $\begin{array}{l}62.1 \\
(11.1)\end{array}$ & $\begin{array}{l}<0.0 \\
001\end{array}$ \\
\hline $\begin{array}{l}\text { Body mass } \\
\text { index, kg/ } \\
\text { (SD) }\end{array}$ & $\begin{array}{l}22.3 \\
(2.9)\end{array}$ & $\begin{array}{l}22.9 \\
(3.0)\end{array}$ & $\begin{array}{l}23.4 \\
(3.1)\end{array}$ & $23.6(3.2)$ & $\begin{array}{l}23.7 \\
(3.5)\end{array}$ & $\begin{array}{l}<0.0 \\
001\end{array}$ \\
\hline $\begin{array}{l}\text { Systolic } \\
\text { blood } \\
\text { pressure, } \\
\text { mmHg (SD) }\end{array}$ & $\begin{array}{l}109.1 \\
(6.8)\end{array}$ & $\begin{array}{l}122.2 \\
(4.6)\end{array}$ & $\begin{array}{l}132.5 \\
(4.8)\end{array}$ & $144.4(7.8)$ & $\begin{array}{l}162.0 \\
(9.5)\end{array}$ & $\begin{array}{l}<0.0 \\
001\end{array}$ \\
\hline $\begin{array}{l}\text { Diastolic } \\
\text { blood } \\
\text { pressure mm } \\
\mathrm{Hg}(\mathrm{SD}) \\
\end{array}$ & $\begin{array}{l}67.4 \\
(6.9)\end{array}$ & $\begin{array}{l}75.2 \\
(7.0)\end{array}$ & $\begin{array}{l}79.5 \\
(7.3)\end{array}$ & $85.3(8.1)$ & $\begin{array}{l}92.9 \\
(9.5)\end{array}$ & $\begin{array}{l}<0.0 \\
001\end{array}$ \\
\hline \multicolumn{7}{|l|}{$\begin{array}{l}\text { Treated } \\
\text { participants } \\
(\mathrm{n}=8098)\end{array}$} \\
\hline Number & 514 & 795 & 1644 & 2817 & 1674 & \\
\hline Women, \% & $\begin{array}{l}336 \\
(65.4)\end{array}$ & $\begin{array}{l}511 \\
(64.3)\end{array}$ & $\begin{array}{l}1004 \\
(61.1)\end{array}$ & $\begin{array}{l}1700 \\
(60.3)\end{array}$ & $\begin{array}{l}978 \\
(58.4)\end{array}$ & $\begin{array}{l}0.01 \\
7\end{array}$ \\
\hline $\begin{array}{l}\text { History of } \\
\text { cardiovascul } \\
\text { ar } \\
\text { disease, \% }\end{array}$ & $\begin{array}{l}85 \\
(16.5)\end{array}$ & $\begin{array}{l}124 \\
(15.6)\end{array}$ & $\begin{array}{l}276 \\
(16.8)\end{array}$ & $536(19.1)$ & $\begin{array}{l}353 \\
(21.3)\end{array}$ & $\begin{array}{l}<0.0 \\
001\end{array}$ \\
\hline $\begin{array}{l}\text { Diabetes } \\
\text { mellitus, \% }\end{array}$ & $\begin{array}{l}120 \\
(26.8)\end{array}$ & $\begin{array}{l}123 \\
(17.5)\end{array}$ & $\begin{array}{l}191 \\
(12.7)\end{array}$ & $379(14.3)$ & $\begin{array}{l}239(1 \\
4.6)\end{array}$ & $\begin{array}{l}<0.0 \\
001\end{array}$ \\
\hline $\begin{array}{l}\text { Dyslipidemi } \\
\text { a, \% }\end{array}$ & $\begin{array}{l}144 \\
(30.8)\end{array}$ & $\begin{array}{l}190 \\
(25.6)\end{array}$ & $\begin{array}{l}367 \\
(23.9)\end{array}$ & $581(21.7)$ & $\begin{array}{l}364 \\
(22.4)\end{array}$ & $\begin{array}{l}<0.0 \\
001\end{array}$ \\
\hline $\begin{array}{l}\text { Current or } \\
\text { ex- } \\
\text { smoker, \% }\end{array}$ & $\begin{array}{l}163 \\
(35.3)\end{array}$ & $\begin{array}{l}244 \\
(33.4)\end{array}$ & $\begin{array}{l}536 \\
(36.4)\end{array}$ & $966(37.1)$ & $\begin{array}{l}610 \\
(39.0)\end{array}$ & 0.15 \\
\hline $\begin{array}{l}\text { Current or } \\
\text { ex-drinking } \\
\text { habits, \% }\end{array}$ & $\begin{array}{l}205 \\
(44.4)\end{array}$ & $\begin{array}{l}302 \\
(41.7)\end{array}$ & $\begin{array}{l}665 \\
(45.2)\end{array}$ & $\begin{array}{l}1153 \\
(44.2)\end{array}$ & $\begin{array}{l}727 \\
(46.4)\end{array}$ & 0.43 \\
\hline Age, y(SD) & $\begin{array}{l}65.0 \\
(9.2)\end{array}$ & $\begin{array}{l}65.2 \\
(9.1)\end{array}$ & $\begin{array}{l}65.4 \\
(8.3)\end{array}$ & $65.5(8.9)$ & $\begin{array}{l}65.2 \\
(9.3)\end{array}$ & 0.73 \\
\hline $\begin{array}{l}\text { Body mass } \\
\text { index, kg/ } \\
\text { (SD) }\end{array}$ & $\begin{array}{l}23.4 \\
(3.4)\end{array}$ & $\begin{array}{l}23.9 \\
(3.1)\end{array}$ & $\begin{array}{l}24.1 \\
(3.3)\end{array}$ & $24.4(3.3)$ & $\begin{array}{l}24.5 \\
(3.3)\end{array}$ & $\begin{array}{l}<0.0 \\
001\end{array}$ \\
\hline $\begin{array}{l}\text { Systolic } \\
\text { blood } \\
\text { pressure, } \\
\text { mmHg (SD) }\end{array}$ & $\begin{array}{l}110.4 \\
(6.4)\end{array}$ & $\begin{array}{l}122.9 \\
(4.4)\end{array}$ & $\begin{array}{l}133.4 \\
(4.5)\end{array}$ & $146.5(7.1)$ & $\begin{array}{l}163.8 \\
(8.3)\end{array}$ & $\begin{array}{l}<0.0 \\
001\end{array}$ \\
\hline $\begin{array}{l}\text { Diastolic } \\
\text { blood } \\
\text { pressure mm } \\
\mathrm{Hg}(\mathrm{SD})\end{array}$ & $\begin{array}{l}67.5 \\
(7.3)\end{array}$ & $\begin{array}{l}74.6 \\
(7.8)\end{array}$ & $\begin{array}{l}78.8 \\
(8.3)\end{array}$ & $85.0(8.6)$ & $\begin{array}{l}92.1 \\
(10.1)\end{array}$ & $\begin{array}{l}<0.0 \\
001\end{array}$ \\
\hline
\end{tabular}

Table 5 Correlation between negative psychological factors and cardiovascular events and diseases

\begin{tabular}{|c|c|c|}
\hline $\begin{array}{l}\text { Negative psychological } \\
\text { factors }\end{array}$ & Parameter & Effect estimates $(95 \% \mathrm{CI})$ \\
\hline \multirow[t]{6}{*}{ Depression } & Incident MI & $\begin{array}{l}\text { Risk Ratio(RR), } \\
1.30(1.22-1.40)\end{array}$ \\
\hline & Incident CHD & RR, 1.30(1.18-1.44) \\
\hline & Stroke & RR, 1.45(1.31-1.61) \\
\hline & Obesity & RR, 1.37(1.17-1.48) \\
\hline & Hypertension & $\mathrm{RR}, 1.42(1.09-1.86)$ \\
\hline & Diabetes & RR, 1.32(1.18-1.47) \\
\hline \multirow[t]{5}{*}{ Anxiety } & CVD mortality & RR, 1.41(1.13-1.76) \\
\hline & Incident CHD & $\mathrm{RR}, 1.41(1.23-1.61)$ \\
\hline & $\begin{array}{l}\text { Coronary artery } \\
\text { spasm }\end{array}$ & RR, 5.20(4.72-5.40) \\
\hline & Incident stroke & RR, 1.71(1.18-2.50) \\
\hline & Heart failure & RR, 1.35(1.11-1.64) \\
\hline Work-related stress & $\begin{array}{l}\text { Incident CVD } \\
\text { events }\end{array}$ & RR, 1.40(1.20-1.80) \\
\hline Any-cause stress & Incident CHD & $\mathrm{RR}, 1.27(1.12-1.45)$ \\
\hline PTSD & Incident CHD & RR, 1.61(1.46-1.77) \\
\hline $\begin{array}{l}\text { Social isolation and } \\
\text { loneliness }\end{array}$ & $\begin{array}{l}\text { Incident CVD } \\
\text { events }\end{array}$ & RR, 1.50(1.20-1.90) \\
\hline Pessimism & CHD mortality & $\begin{array}{l}\text { Odds Ratio(OR), } \\
2.17(1.21-3 \text {. }\end{array}$ \\
\hline \multirow[t]{2}{*}{ Anger and hostility } & Incident CHD & HR, $1.19(1.05-1.35)$ \\
\hline & Recurrent CHD & HR, 1.24(1.08-1.42) \\
\hline
\end{tabular}

\section{References}

1. Asayama, K., Satoh, M., Murakami, Y., Ohkubo, T., Nagasawa, S. Y., Tsuji, I., ... \& Miyamoto, Y. (2014). Cardiovascular risk with and without antihypertensive drug treatment in the Japanese general population: participant-level metaanalysis. Hypertension, 63(6), 1189-1197.

2. Ikeda, A., Iso, H., Yamagishi, K., Inoue, M., \& Tsugane, S. (2009). Blood pressure and the risk of stroke, cardiovascular disease, and all-cause mortality among Japanese: the JPHC Study. American journal of hypertension, 22(3), 273-280.

3. Lawes CM,VAnder Hoorn S,Rodgers A,et al.International Society of Hypertension.Global burden blood-pressure-related disease ,2001.lancet, 2008, 371(9623): 1513-1518

4. Joel Nuotio,Karri Suvila,Susan Cheng,et al.Longitudinal Blood Pressure Pattern Cardiovascular Disease Risk.Ann Med,2020,Online ahead of print.

5. Allen NB,Siddique J,Wilkins JT,et al.Ten-year blood pressure trajectories, cardiovascular mortality, and life years lost in 2 extinction cohorts:the Minnesota Business and Professuina Study and the Zutphen Study.J Am Heart Assoc,2015,4(3):e001378. 
6. Yasui D, Asayama K, Ohkubo T, Kikuya M, Kanno A, Hara A, Hirose T, Obara T, Metoki H, Inoue R, Totsune K, Hoshi H, Satoh H, Imai Y. Stroke risk in treated hypertension based on home blood pressure: the Ohasama study.Am J Hypertens. 2010; 23:508514.

7. Glenn N. Levine, Beth E. Cohen, Yvonne Commodore-Mensah, et al. AHA SCIENTIFIC STATEMENT: Psychological Health, Well-Being, and the Mind-Heart-Body Connection. A Scientific Statement From the American Heart Association. Circulation. 2021; 143: 00-00. DOI: 10.1161/CIR.0000000000000947

8. Megan Brooks. New AHA Scientific Statement on Mind-Heart-Body Connection. Medscape. January 25, 2021.

9. Okamura T, Sugiyama D, Tanaka T, Dohi S. Worksite wellness for the primary and secondary prevention of car- diovascular disease in Japan: the current delivery system and future directions. Prog Cardiovasc Dis, 2014; 56: 515-521

10. Hozawa A, Kuriyama S, Watanabe I, Kakizaki M, Ohm- ori-Matsuda K, Sone T, Nagai M, Sugawara Y, Nitta A, Li Q, Ohkubo T, Murakami Y, Tsuji I. Participation in health check-ups and mortality using propensity score matched cohort analyses. Prev Med, 2010; 51: 397-402. 